Supporting Information for

\title{
Photochemical Disulfide-Ene Modification Enhances Protein Sequencing and Disulfide Mapping by Mass Spectrometry
}

\author{
Xiaoyue Yang, Longfei Zhang, and Yu Xia* \\ Department of Chemistry, Tsinghua University, Beijing 100084, P.R. China \\ Corresponding Author Information: \\ E-mail:xiayu@mail.tsinghua.edu.cn
}

\section{Table of Contents}

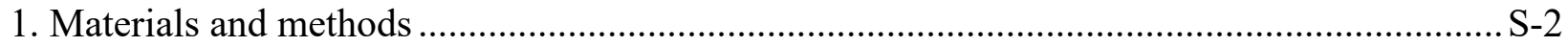

2. Disulfide-ene reaction using different alkenes $\quad$....................................................... S-5

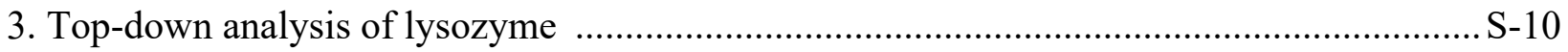

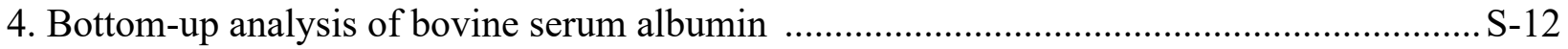




\section{Materials and methods}

\section{Materials.}

Tris- $\mathrm{HCl}$ was purchased from Biodee (Beijing, China). Trypsin and endo-proteinase Lys-C mix were purchased from Promega (Madison, WI, USA). LC grade IPA, acetone, acetonitrile (ACN), and formic acid (FA) were from Fisher Chemical (Pittsburgh, PA, USA). Lysozyme from egg white and bovine serum albumin were purchased from Aladdin (Shanghai, China). Selectin peptide was purchased from GL Biochem Ltd. (Shanghai, China). Oxidized glutathione was purchased from TCI Ltd. (Tokyo, Japan). 1-Octene was purchased from Rhawn (Shanghai, China). Norbornene, 2-allyloxyethanol, and $\beta$-caryophyllene were purchased from Energy Chemical (Shanghai, China). 2,3-Dihydrofuran was purchased from Innochem (Beijing, China).

\section{Protein digestion.}

The stock solution of peptide or protein $(8 \mathrm{mg} / \mathrm{mL})$ was prepared in Tris- $\mathrm{HCl}$ buffer $(\mathrm{pH} 6.5)$ containing $8 \mathrm{M}$ urea. The solution was subsequently incubated at $37{ }^{\circ} \mathrm{C}$ for $2 \mathrm{~h}$, added with Lys-C Trypsin mix to reach a final enzyme: protein ratio of 1:20 (w/w) and diluted using Tris- $\mathrm{HCl}$ buffer (pH 6.5) to a final concentration of $1 \mathrm{mg} / \mathrm{mL}$. Finally, after incubated overnight at $37{ }^{\circ} \mathrm{C}$, the digestion was quenched by the addition of $2 \%(v / v)$ FA.

\section{The direct-infusion setup.}

A low-pressure mercury UV lamp with an emission band around 254 nm (BHK, Inc., Ontario, CA) was used to initiate the photochemical reactions. Reaction solution flowing through UVtransparently coated silica capillary $(100 \mu \mathrm{m}$, i.d., $363 \mu \mathrm{m}$, o.d.; Innosep, Zhengzhou, China) was irradiated parallelly with the lamp from $0.5 \mathrm{~cm}$ away. A tinfoil box was used to enclose photoreaction setups so that human exposure to UV light could be avoided and limit irradiated region $(\sim 5 \mathrm{~cm})$ enables an adjust of r.t. by controlling flow rate. Flow-out was either collected or directly 
injected into ESI. $80 \% \mathrm{H}_{2} \mathrm{O}, 20 \%$ IPA, $1 \%$ acetone, $1 \% \mathrm{HCOOH}$ and $2 \mathrm{mM}$ norbornene solvent conditions were used for the lysozyme top-down analysis. A TIMS-TOF mass spectrometer (Bruker Daltonics, Bremen, Germany) was employed for acquiring high-resolution $\mathrm{MS}^{1}$, MS/MS data.

\section{Liquid chromatography.}

All LC separations were performed on a 20AD LC system (SHIMADZU, Tokyo, Japan) connected to an X500R QTOF mass spectrometer (SCIEX, Toronto, CA). An Ascentis C18 reversed-phase column was used $(2.7 \mu \mathrm{m}, 3.0 \mathrm{~mm} \times 150 \mathrm{~mm}$, Sigma Aldrich, St. Louis, MO, USA). The mobile phase A and B were water and ACN, respectively, both containing $0.1 \%$ FA. A flow rate of 200 $\mu \mathrm{L} /$ min was used with a linear gradient starting from $5 \%$ to $45 \%$ mobile phase $\mathrm{B}$ over 70 min for the digest of bovine serum albumin.

\section{Coupling online photochemical reduction onto an LC-MS system.}

A flow microreactor was installed post LC separation and right before ESI. The reactor was made with a UV-transmitting FEP tubing (0.03-in. i.d., 1/16 o.d., Zeus Inc., Orangeburg, SC, USA) elongated into $15 \mathrm{~cm}$ and coiled in $3 \mathrm{~cm}$ diameter with the UV lamp centered in it. The reaction time was tunable in the range of $10 \mathrm{~s}$ to $15 \mathrm{~s}$. To achieve full reduction, a photo-initiating solution consisting of $10 \%$ acetone, $90 \%$ IPA and $5 \mathrm{mmol} / \mathrm{L}$ norbornene was pumped to the LC eluent through a T-junction at $50 \mu \mathrm{L} / \mathrm{min}$ before going through the flow microreactor. And photoinitiating solution consisting of $7.5 \%$ acetone, $92.5 \%$ IPA and $5 \mathrm{mmol} / \mathrm{L}$ norbornene was adopted for partial reduction.

\section{Data analysis.}

MASH software was used for top-down sequence coverage analysis. The data from the TIMSTOF mass spectrometer (Bruker Daltonics, Bremen, Germany) could directly be imported into the 
software and discovery mode was used to process the data. TopFD Method was employed to deconvolute the $\mathrm{MS}^{2}$ data and then database search was carried out using the MS-Align+ method. The error tolerance was $20 \mathrm{ppm}$. 


\section{Disulfide-ene reaction using different alkenes}

Table S1. The percentage of disulfide cleavage and alkene addition products for different alkenes. The \% S-S cleavage was calculated from $\left(\left({ }^{1 \mathrm{E}} \mathrm{I}+{ }^{2 \mathrm{E}} \mathrm{I}+{ }^{\mathrm{R}} \mathrm{I}\right) /\left({ }^{1 \mathrm{E}} \mathrm{I}+{ }^{2 \mathrm{E}} \mathrm{I}+{ }^{\mathrm{R}} \mathrm{I}+{ }^{\text {intact }} \mathrm{I}\right) \times 100 \%\right)$. The $\%\left[{ }^{1 \mathrm{E}} \mathrm{M}+2 \mathrm{H}\right]{ }^{2+}$ was calculated from $\left({ }^{1 \mathrm{E}} \mathrm{I} /\left({ }^{1 \mathrm{E}} \mathrm{I}+{ }^{2 \mathrm{E}} \mathrm{I}+{ }^{\mathrm{R}} \mathrm{I}+{ }^{\text {intact }} \mathrm{I}\right) \times 100 \%\right)$. The $\%\left[{ }^{2 \mathrm{E}} \mathrm{M}+2 \mathrm{H}\right]{ }^{2+}$ was calculated from $\left({ }^{2 \mathrm{E}} \mathrm{I} /\left({ }^{1 \mathrm{E}} \mathrm{I}+{ }^{2 \mathrm{E}} \mathrm{I}+{ }^{\mathrm{R}} \mathrm{I}+{ }^{\text {intact }} \mathrm{I}\right) \times 100 \%\right)$.

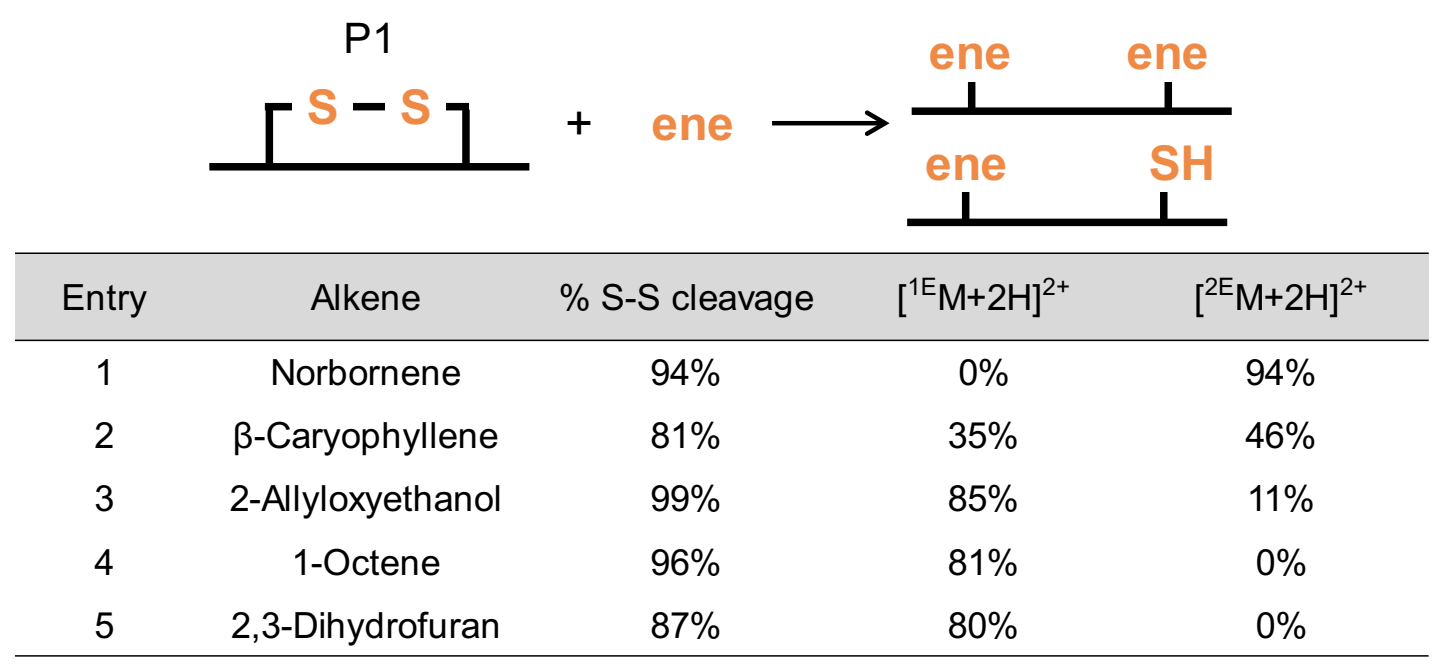


P1 CIELLQARC

a
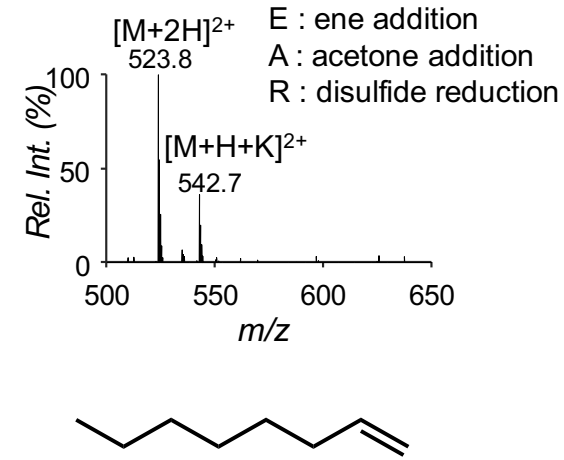

C

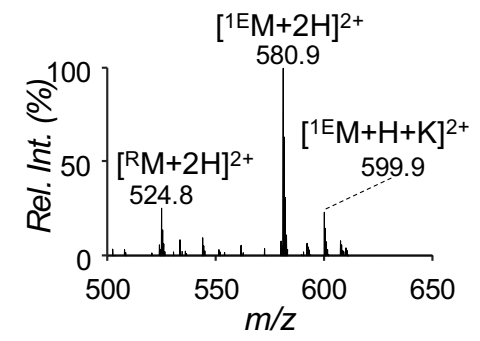

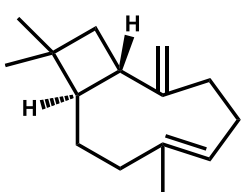

b
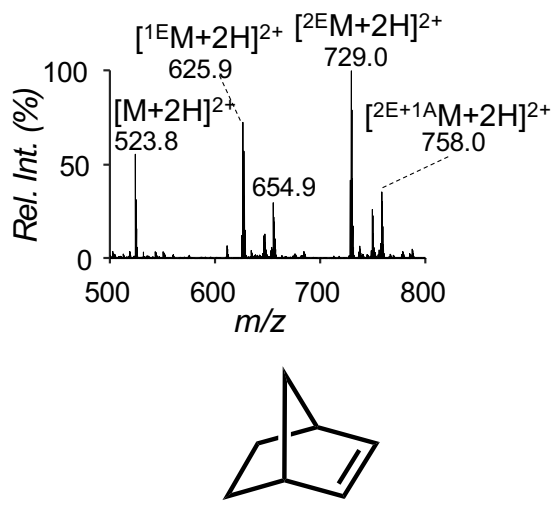

d

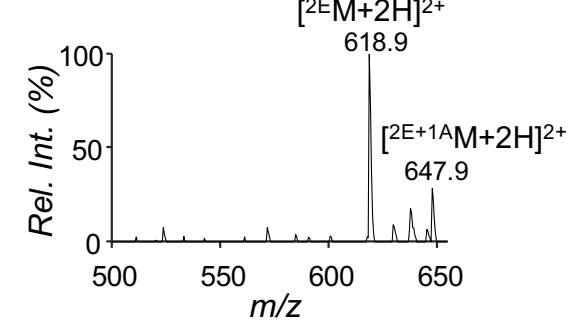

Figure S1. (a) Positive ion mode $\mathrm{MS}^{1}$ spectrum of selectin binding peptide $(\mathrm{P} 1,4 \mu \mathrm{M})$. Positive ion mode $\mathrm{MS}^{1}$ spectrum of disulfide-ene reaction of P1 (4 $\left.\mu \mathrm{M}\right)$ with (b) $\beta$-caryophyllene, (c) 1octene, and (d) norbornene after $5 \mathrm{~s}$ UV exposure. The solvent condition was $70 \% \mathrm{H}_{2} \mathrm{O}, 30 \%$ IPA, $1 \% \mathrm{HCOOH}$, and $1 \%$ acetone. 


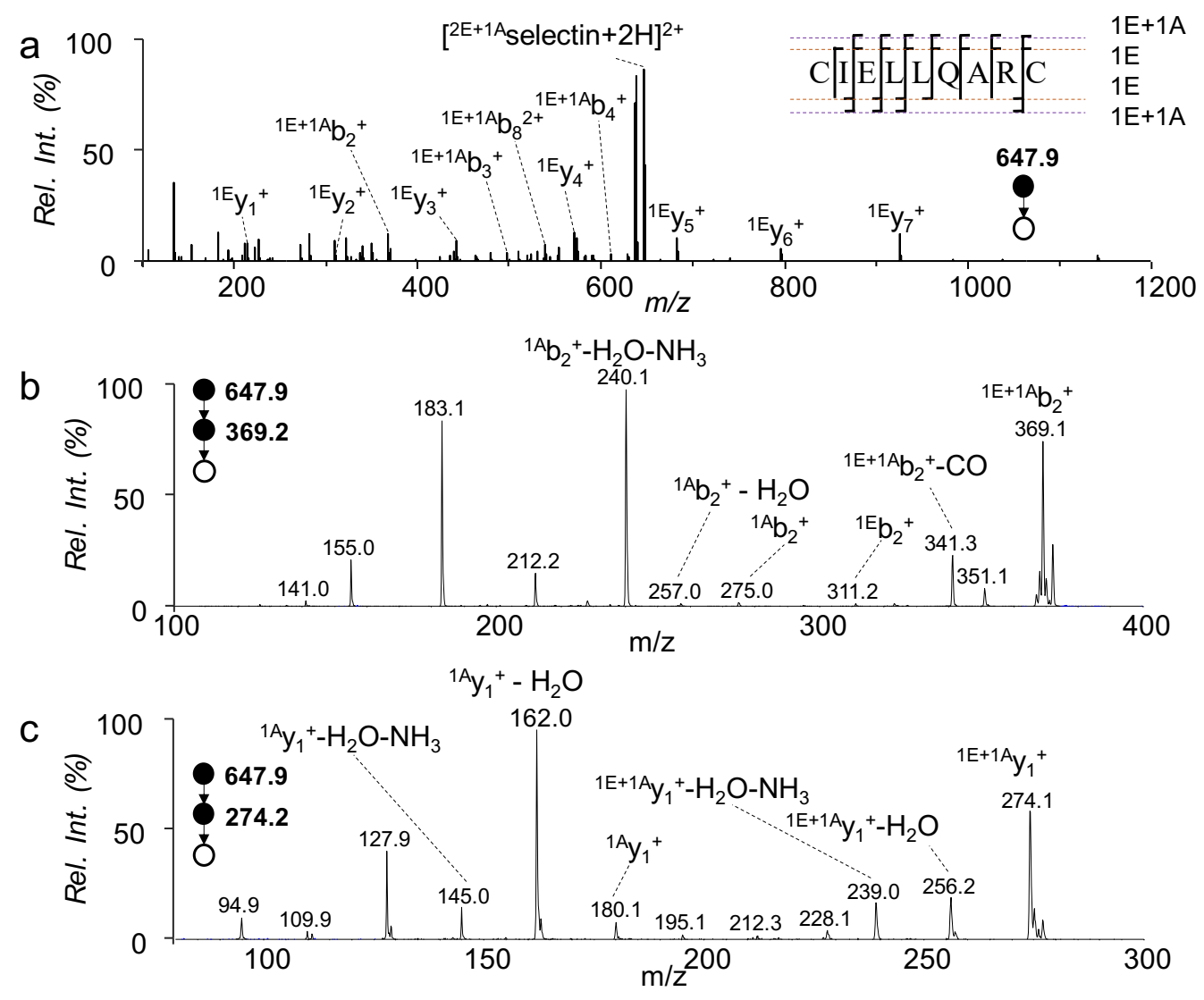

Figure S2. (a) Positive ion mode $\mathrm{MS}^{2}$ CID spectrum of the 1 acetone and 2 norbornene addition $(2 \mathrm{E}+1 \mathrm{~A})$ product to $\mathrm{P} 1(4 \mu \mathrm{M})$ after $1.6 \mathrm{~s} \mathrm{UV}$ exposure. $\mathrm{MS}^{3}$ CID spectra of $(\mathrm{b})^{1 \mathrm{E}+1 \mathrm{~A}} \mathrm{~b}_{2}{ }^{+}$and (c) ${ }^{1 E+1 A} \mathrm{y}_{1}^{+}$generated from (a). 


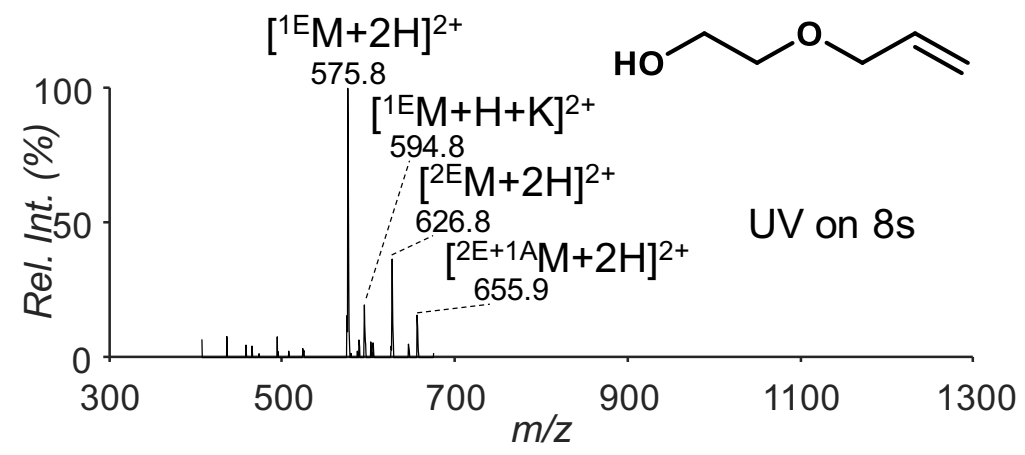

Figure S3. Positive ion mode $\mathrm{MS}^{1}$ spectrum of disulfide-ene reaction with 2-allyloxyethanol using selectin binding peptide $(4 \mu \mathrm{M})$ as model peptide after $8 \mathrm{~s}$ UV exposure. The solvent condition was $70 \% \mathrm{H}_{2} \mathrm{O}, 30 \%$ IPA, $1 \% \mathrm{HCOOH}$ and $1 \%$ acetone.
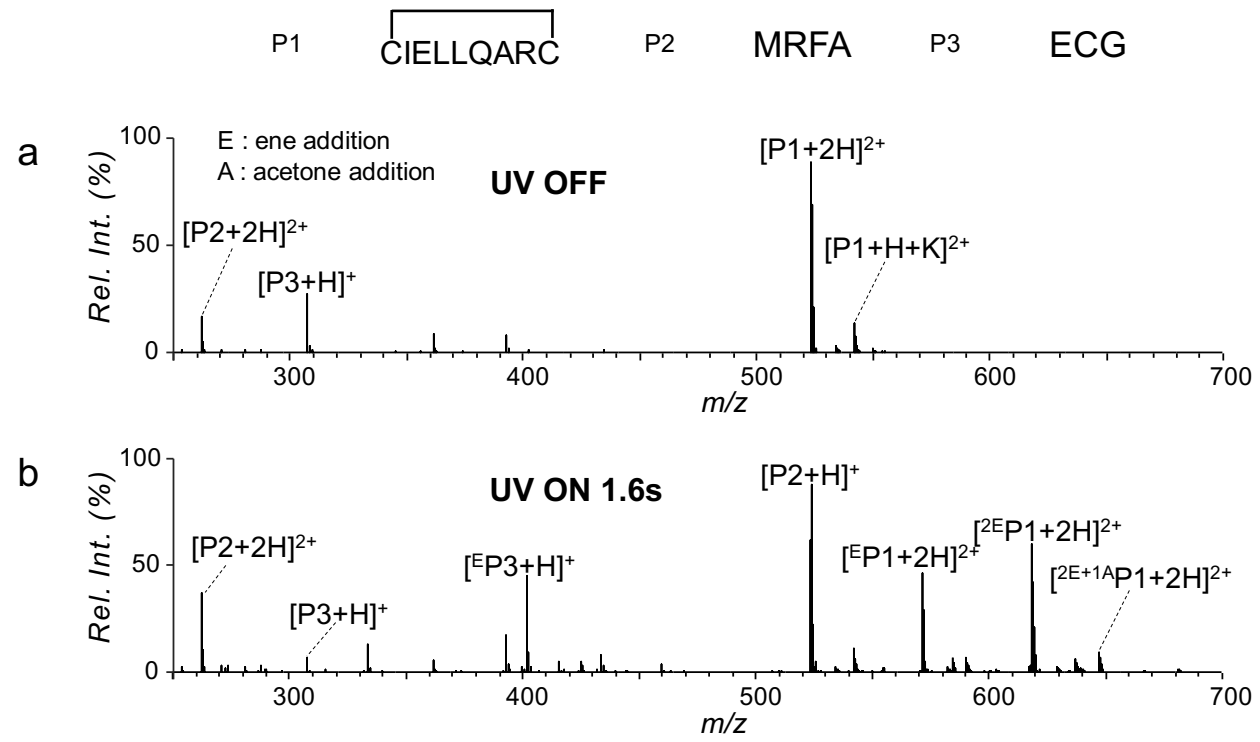

Figure S4. (a) Positive ion mode $\mathrm{MS}^{1}$ spectrum of an equal molar mixture ( $4 \mu \mathrm{M}$ each) of selectin binding peptide (P1), MRFA peptide (P2) and reduced glutathione (P3). The solvent contained 70\% $\mathrm{H}_{2} \mathrm{O}, 30 \%$ IPA, $1 \% \mathrm{HCOOH}, 1 \%$ acetone, and $1 \mathrm{mM}$ norbornene. (b) $\mathrm{MS}^{1}$ spectrum of the mixture after $1.6 \mathrm{~s} \mathrm{UV}$ exposure. 

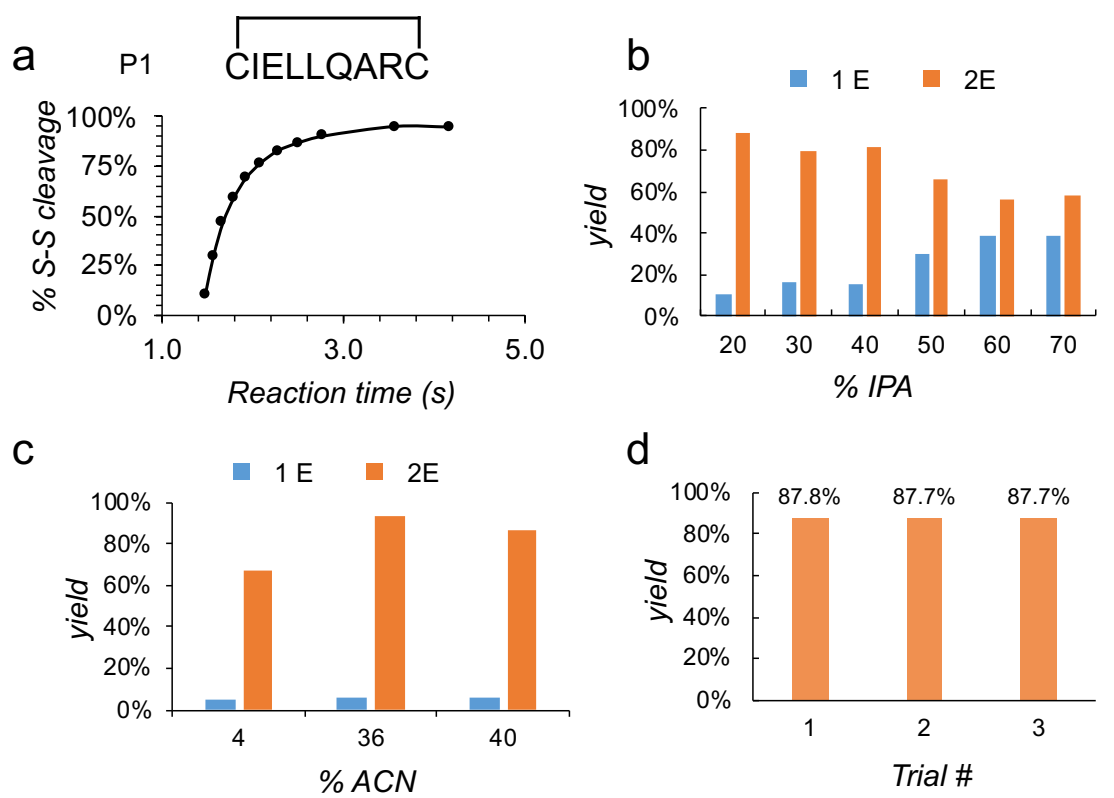

Figure S5. (a) A plot of \%S-S cleavage as a function of UV exposure time of $\mathrm{P} 1(4 \mu \mathrm{M})$ in a solvent containing $1 \mathrm{mM}$ norbornene, $70 \% \mathrm{H}_{2} \mathrm{O}, 30 \% \mathrm{IPA}, 1 \% \mathrm{HCOOH}$, and $1 \%$ acetone. (b) The product yield under different \%IPA in the IPA- $\mathrm{H}_{2} \mathrm{O}$ solvent system. Acetone was kept at $2 \%$. (c) The product yield under different \%ACN in the ACN-IPA $(18 \%)-\mathrm{H}_{2} \mathrm{O}$ solvent system. Acetone was kept at $2 \%$. (d) The yield of the double-ene addition product from three repeats $(87.7 \pm 0.1 \%)$. Reaction time: $5 \mathrm{~s}$; solvent condition: $1 \mathrm{mM}$ norbornene, $70 \% \mathrm{H}_{2} \mathrm{O}, 30 \% \mathrm{IPA}, 1 \% \mathrm{HCOOH}$, and $1 \%$ acetone. 


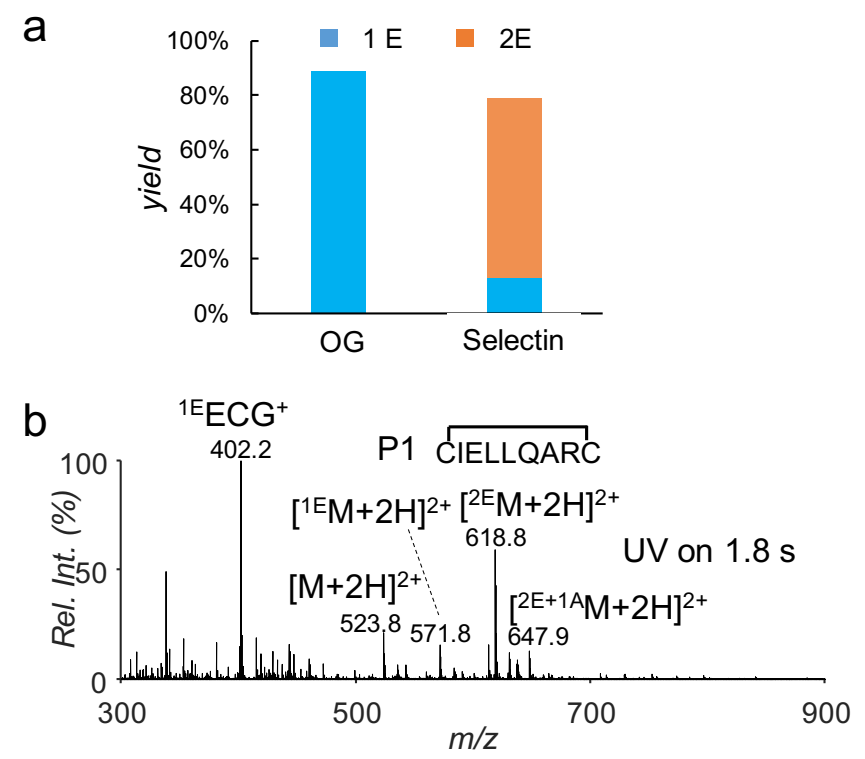

Figure S6. (a) A comparison of the disulfide-ene reaction yield of an equal molar mixture of oxidized glutathione $(\mathrm{OG})$ and $\mathrm{P} 1$ after $1.8 \mathrm{~s}$ reaction. (b) Corresponding $\mathrm{MS}^{1}$ spectrum after 1.8 s reaction.

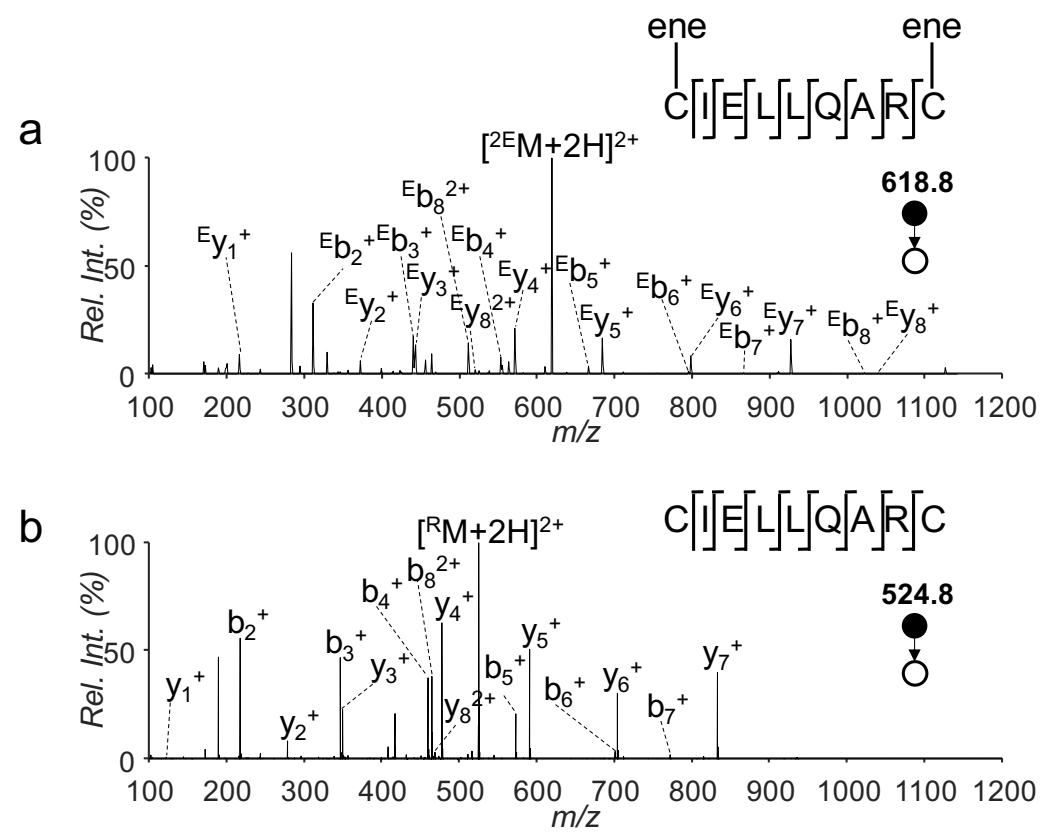

Figure S7. Positive ion mode $\mathrm{MS}^{2}$ CID spectrum of (a) the disulfide-ene product of P1. (b) the acetone-induced reduction product of $\mathrm{P} 1$. 


\section{Top-down analysis of lysozyme}

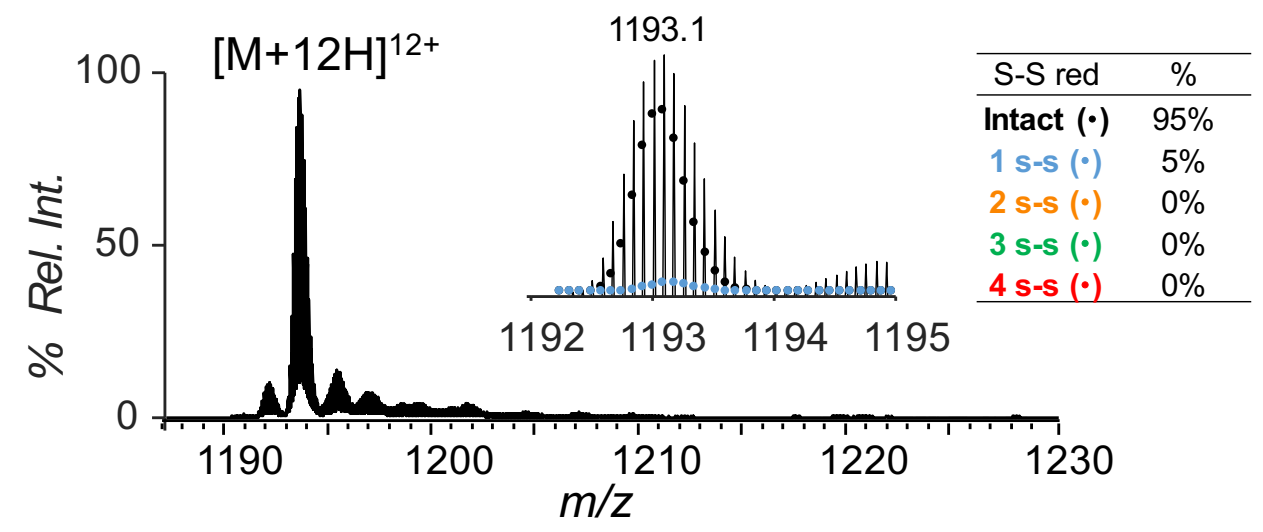

Figure S8. Positive ion mode $\mathrm{MS}^{1}$ spectra of intact $[\mathrm{M}+12 \mathrm{H}]^{12+}(\mathrm{m} / \mathrm{z} 1193.1)$ ions of Lysozyme (4 disulfide bonds, $14 \mathrm{kDa}$ ).

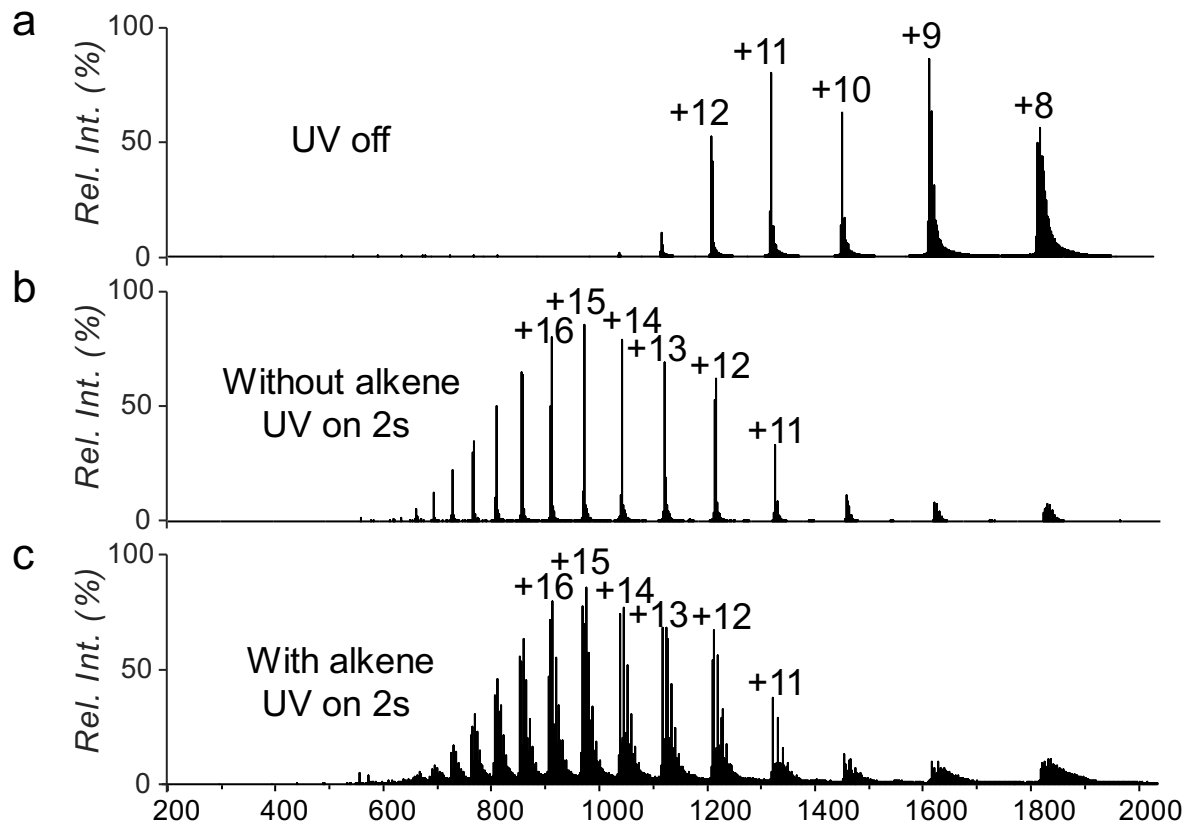

Figure S9. Positive ion mode $\mathrm{MS}^{1}$ spectrum of (a) $35 \mu \mathrm{M}$ lysozyme (4 disulfide bonds) before reaction. The solvent contained $80 \% \mathrm{H}_{2} \mathrm{O}, 20 \%$ IPA, $1 \% \mathrm{HCOOH}, 1 \%$ acetone, and $2 \mathrm{mM}$ norbornene. (b) The reaction spectrum of lysozyme without an addition of norbornene after $2 \mathrm{~s}$ UV exposure. (c) The reaction spectrum of lysozyme with an addition of $2 \mathrm{mM}$ norbornene after $2 \mathrm{~s}$ UV exposure. 


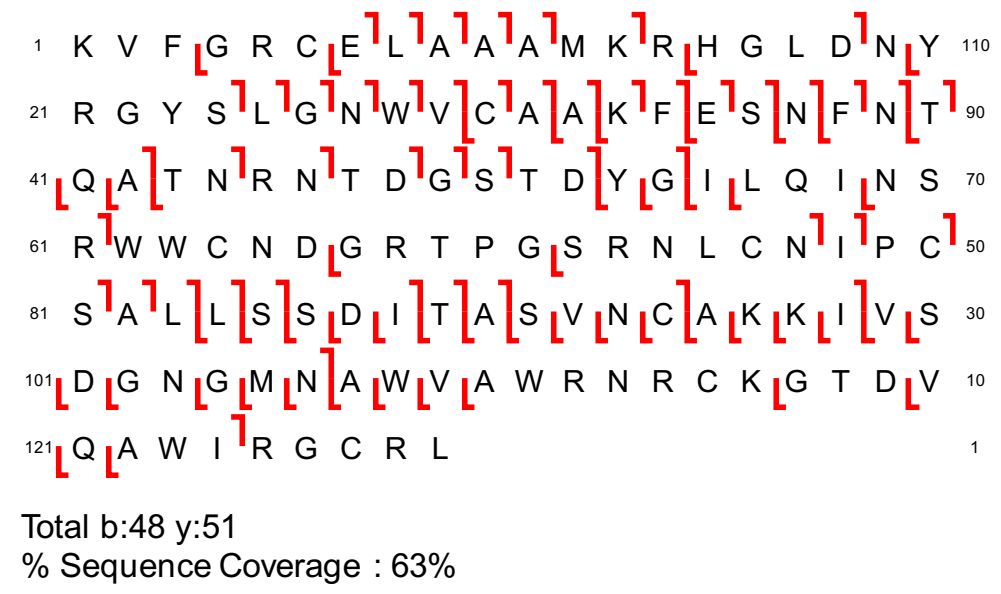

Figure S10. Sequence coverage obtained for lysozyme after acetone-IPA reduction reaction.

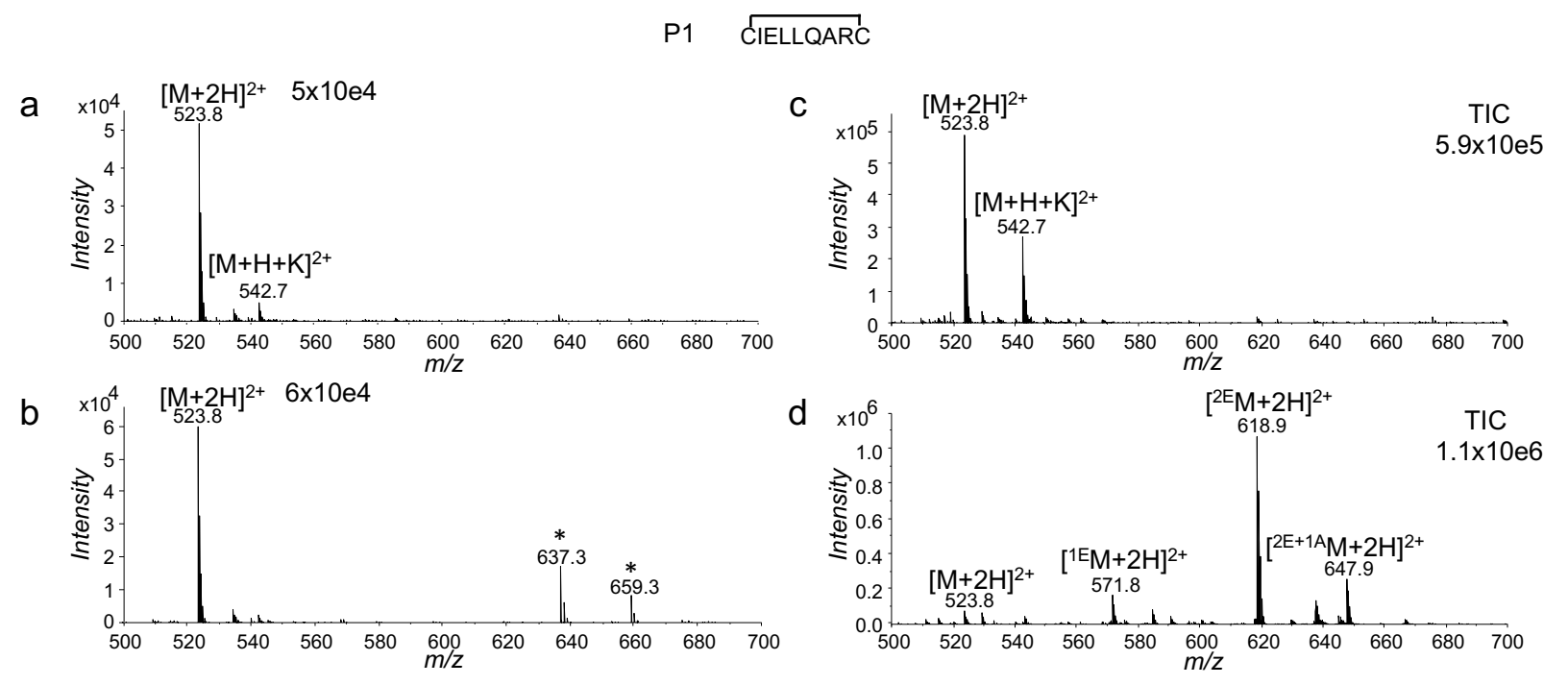

Figure S11. NanoESI MS ${ }^{1}$ spectra of $\mathrm{P} 1$ peptide $(10 \mu \mathrm{M})$ in $70 \% \mathrm{H}_{2} \mathrm{O}, 30 \% \mathrm{IPA}, 1 \% \mathrm{HCOOH}$, and $1 \%$ acetone: (a) without and (b) with an addition of $1 \mathrm{mM}$ norbornene. ESI MS ${ }^{1}$ spectra of P1 peptide $(10 \mu \mathrm{M})$ in $70 \% \mathrm{H}_{2} \mathrm{O}, 30 \%$ IPA, $1 \% \mathrm{HCOOH}$, and $1 \%$ acetone at the presence of $1 \mathrm{mM}$ norbornene: (c) before reaction and (d) after $2.8 \mathrm{~s}$ reaction. The asterisk symbol represents unknown chemical interference. 


\section{Bottom-up analysis of bovine serum albumin}

Disulfide linkage being Identified

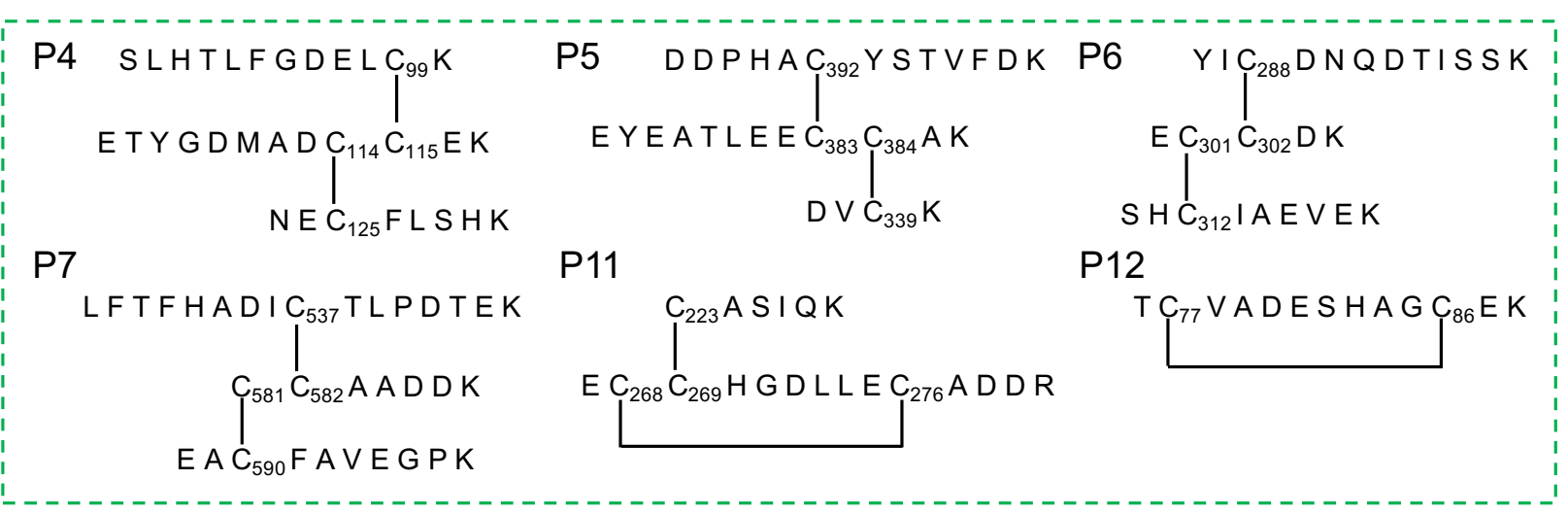

S-S linkage being restricted

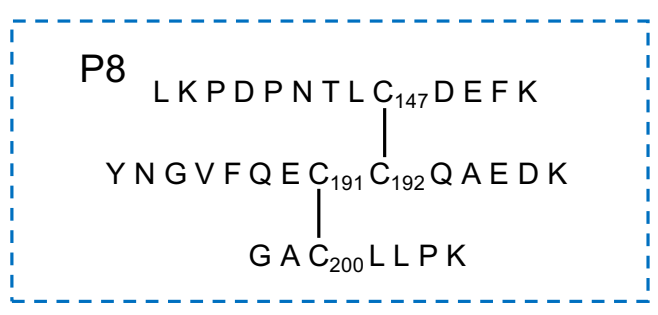

Disulfide peptide not detected

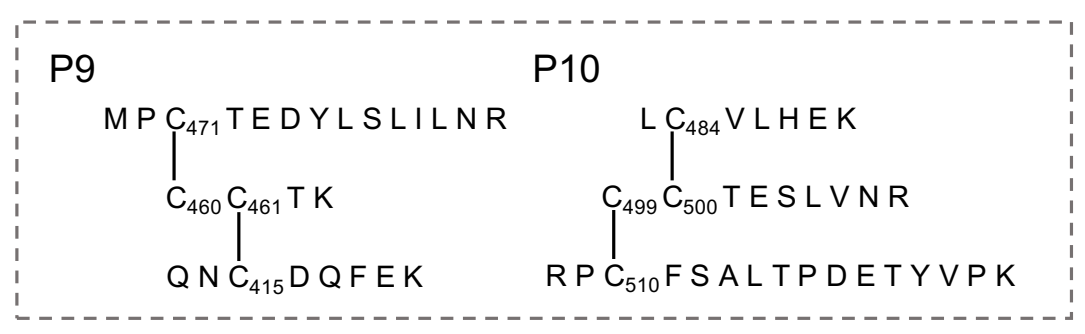

Figure S12. P4-P12 peptides detected from trypsin digestion of BSA. 


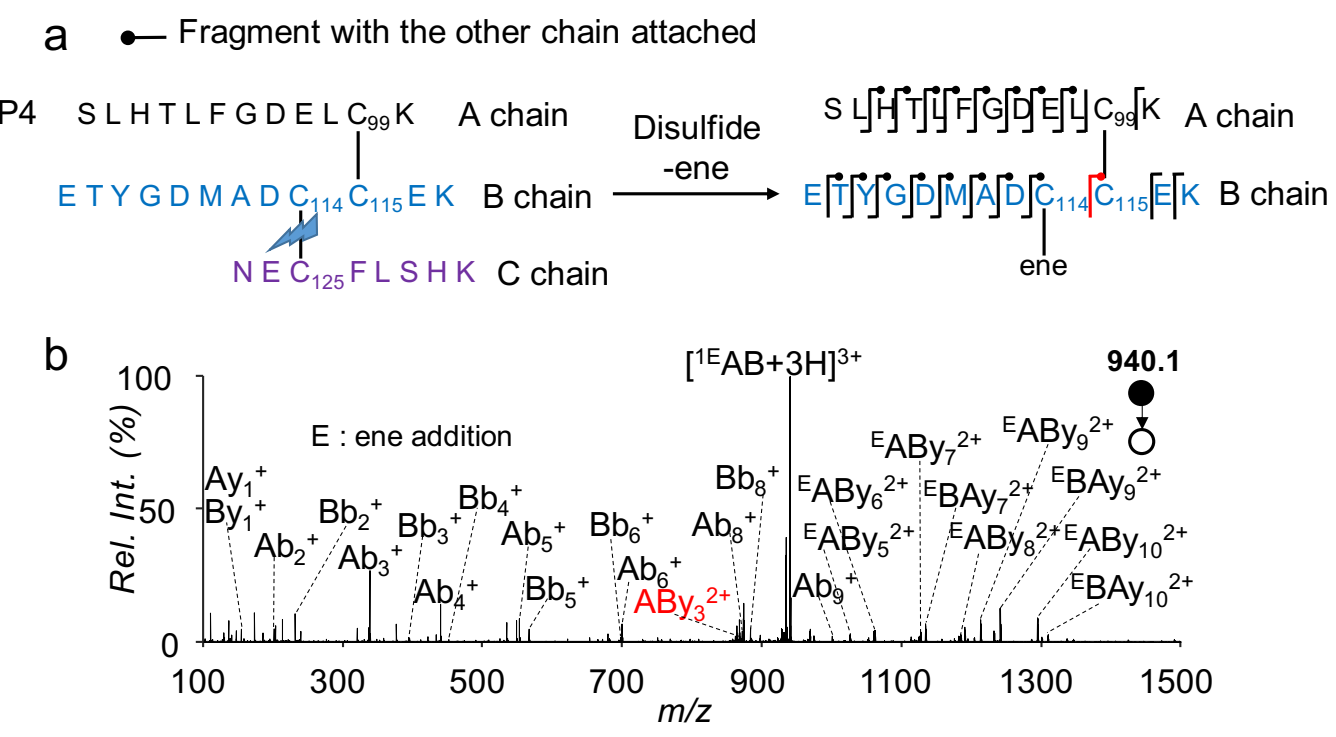

Figure S13. Analysis of P4 peptide derived from trypsin digestion of BSA. (a) Intact P4 and the fragmentation map of its disulfide-ene product. (b) $\mathrm{MS}^{2} \mathrm{CID}$ of disulfide-ene product of $\mathrm{P} 4$ ([ ${ }^{1 \mathrm{E}}$ $\mathrm{AB}+2 \mathrm{H}]^{2+}, m / z$ 940.1).

Because the two cysteine residues are located next to each other $\left(\mathrm{C}_{114}\right.$ and $\left.\mathrm{C}_{115}\right)$ in the $\mathrm{B}$ chain, exact disulfide linkage assignment requires the detection of sequence ions between these two residues. Partial reduction allowed the cleavage of either $\mathrm{C}_{99}-\mathrm{C}_{115}$ or $\mathrm{C}_{114}-\mathrm{C}_{125}$ disulfide bond, thus converting the two-disulfide bond peptide system into a simple disulfide system that only contained one interchain disulfide bond. The detection of sequence ions $\mathrm{By}_{1-2}, \mathrm{ABy}_{3-11}$ and $\mathrm{BAy}_{3-}$ 10 allow confident identification of the $\mathrm{C}_{99}-\mathrm{C}_{115}$ disulfide bond leaving the only option of the $\mathrm{C}_{114-}$ $\mathrm{C}_{125}$ disulfide bond between the $\mathrm{B}$ chain and $\mathrm{C}$ chain. 


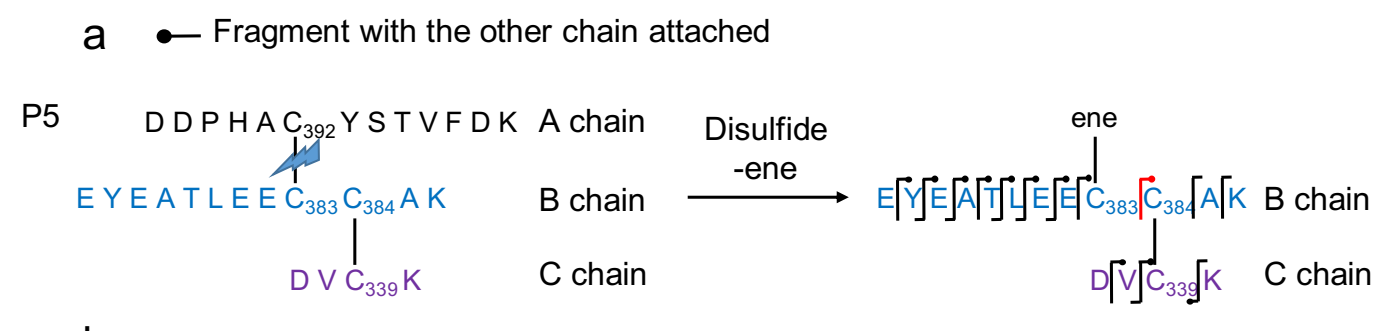

b

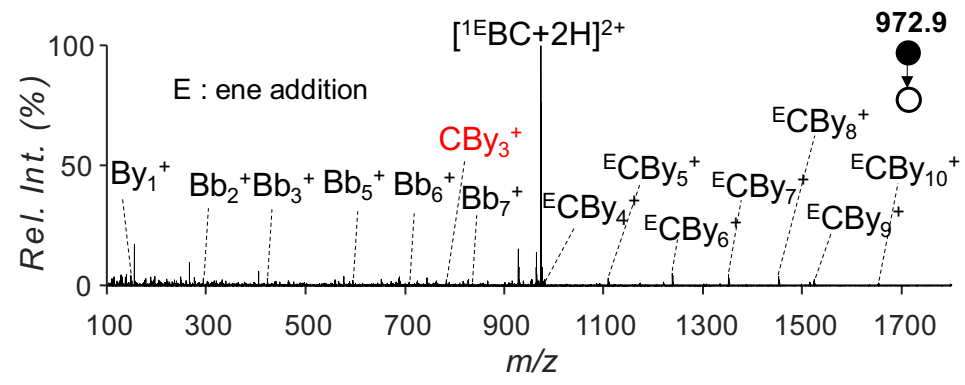

Figure S14. Analysis of P5 peptide derived from trypsin digestion of BSA. (a) Intact P5 and the fragmentation map of its disulfide-ene product. (b) $\mathrm{MS}^{2} \mathrm{CID}$ of disulfide-ene product of P5 ([ ${ }^{1 \mathrm{E}}$ $\mathrm{BC}+2 \mathrm{H}]^{2+}, m / z$ 972.9).

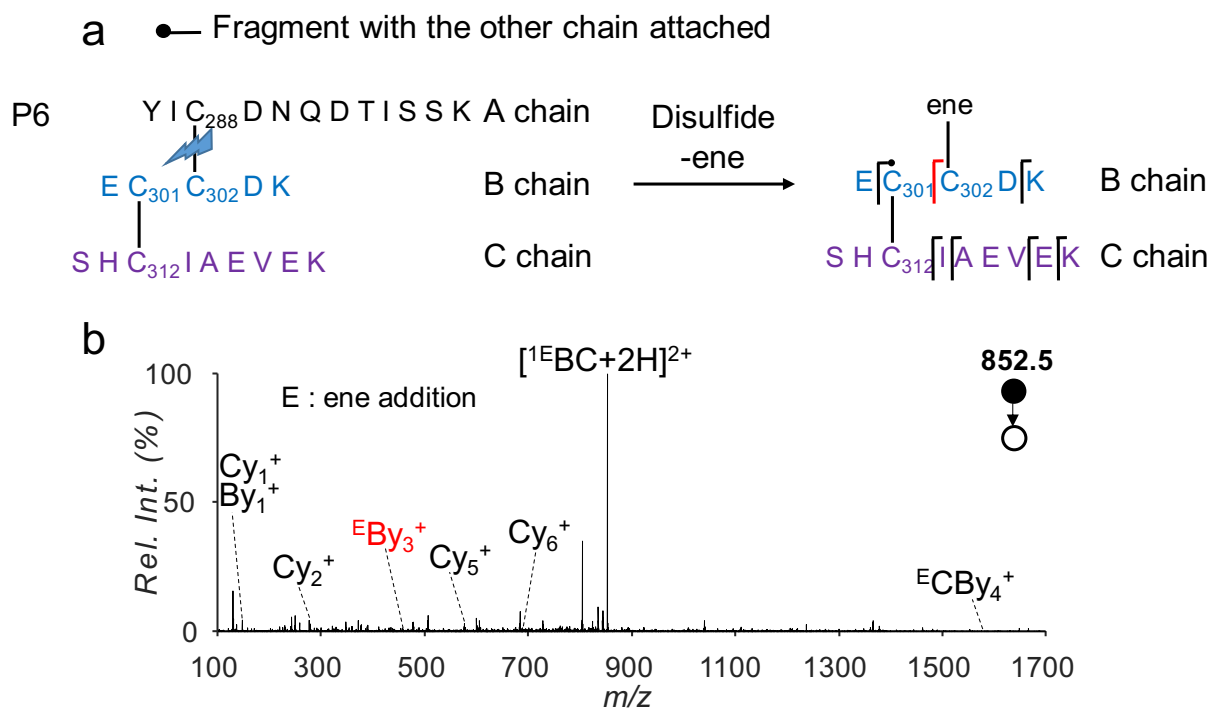

Figure S15. Analysis of P6 peptide derived from trypsin digestion of BSA. (a) Intact P6 and the fragmentation map of its disulfide-ene product. (b) $\mathrm{MS}^{2} \mathrm{CID}$ of disulfide-ene product of P6 ([ ${ }^{1 \mathrm{E}}$ $\left.\mathrm{BC}+2 \mathrm{H}]^{2+}, m / z 852.5\right)$. 


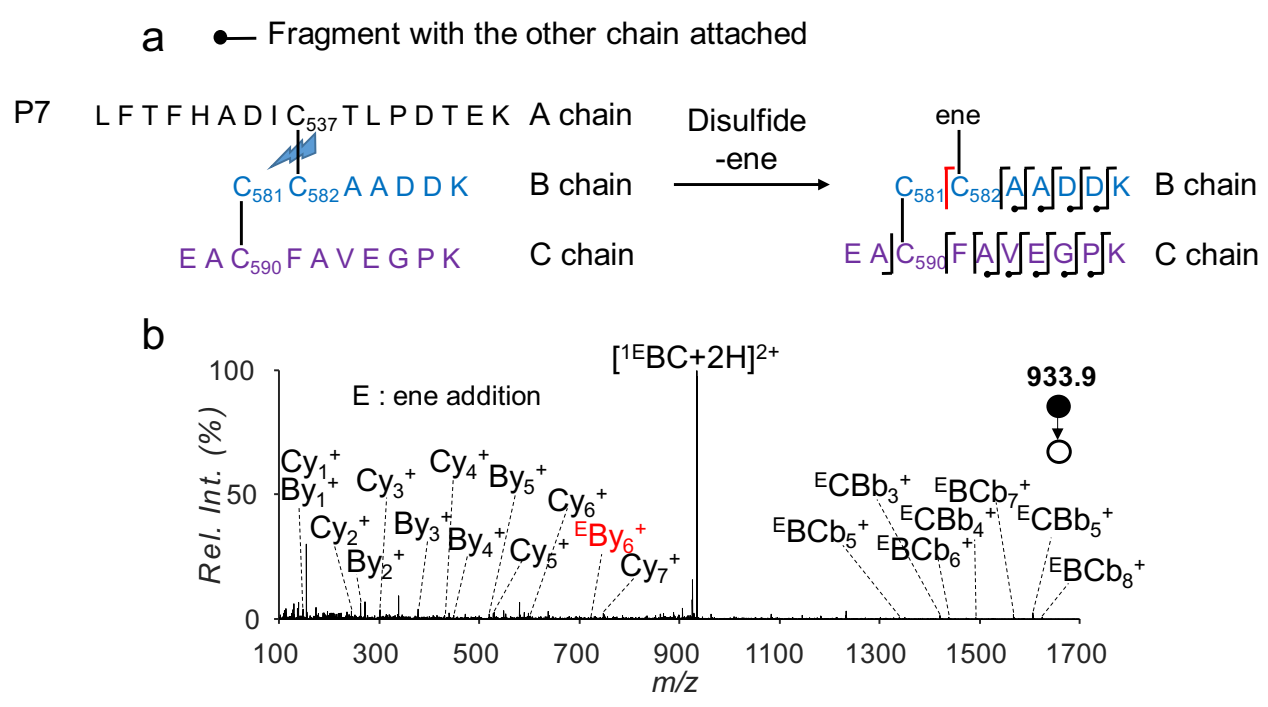

Figure S16. Analysis of P7 peptide derived from trypsin digestion of BSA. (a) Intact P7 and the fragmentation map of its disulfide-ene product. (b) $\mathrm{MS}^{2} \mathrm{CID}$ of disulfide-ene product of $\mathrm{P} 7$ $\left(\left[{ }^{1 \mathrm{E}} \mathrm{BC}+2 \mathrm{H}\right]^{2+}, m / z\right.$ 933.9).

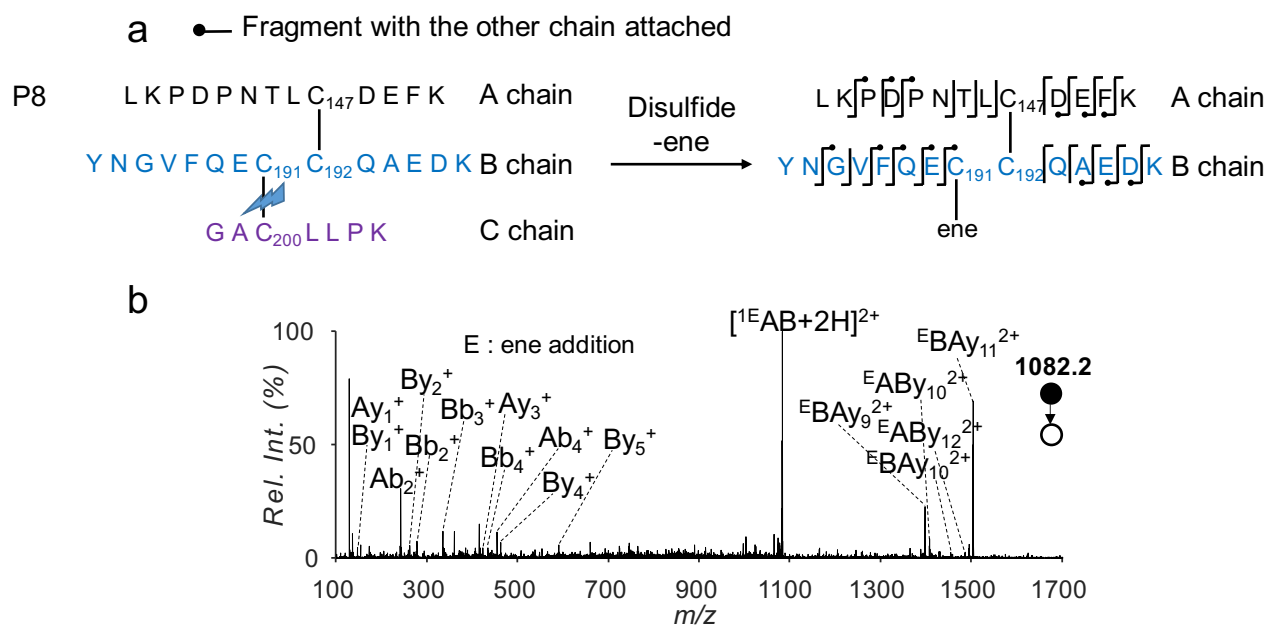

Figure S17. Analysis of P8 peptide derived from trypsin digestion of BSA. (a) Intact P8 and the fragmentation map of its disulfide-ene product. (b) $\mathrm{MS}^{2} \mathrm{CID}$ of disulfide-ene product of $\mathrm{P} 8$ $\left(\left[{ }^{\mathrm{E}} \mathrm{AB}+2 \mathrm{H}\right]^{2+}, m / z\right.$ 1082.2). 


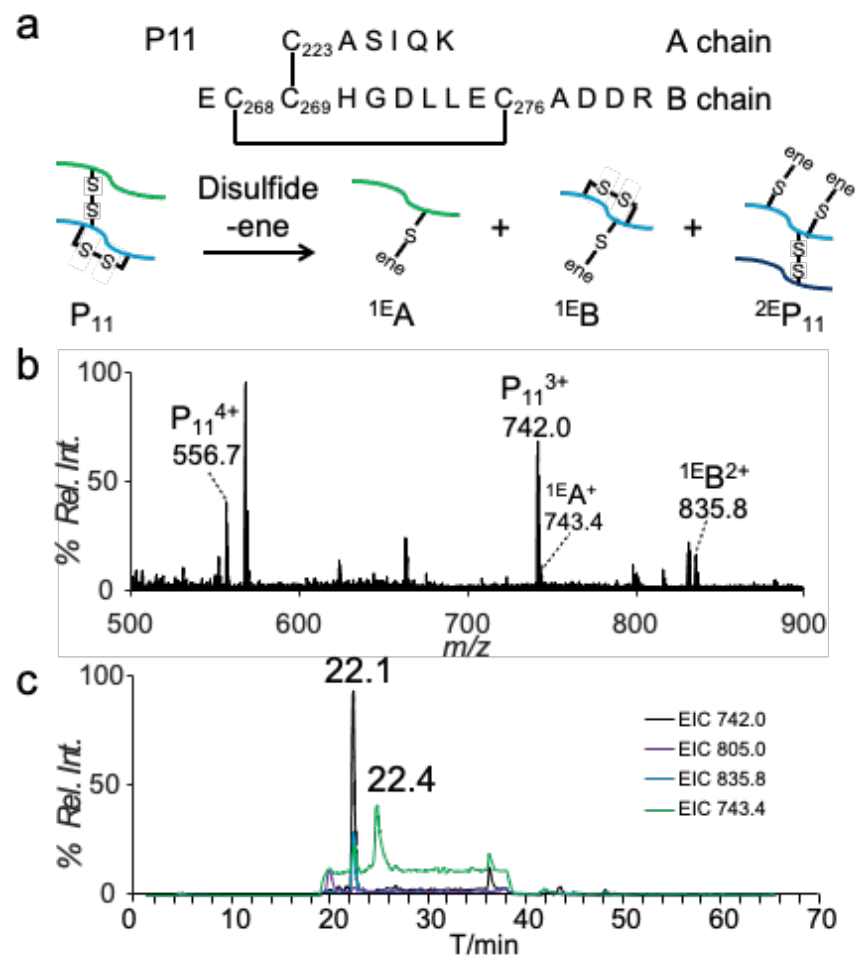

Figure S18. Analysis of P11 peptide from trypsin digestion of BSA. (a) Intact P11 and its disulfide-ene product. (b) Positive ion mode $\mathrm{MS}^{1}$ spectrum of the disulfide-ene product of P11. (c) XIC of the intact P11 and its disulfide-ene product (peak eluted at $22.1 \mathrm{~min}$ ). The increase in the baseline was due to the online UV light-induced reaction which was also witnessed in the acetoneinduced reduction reaction. Besides the peak eluted at $24.4 \mathrm{~min}$, other small peaks in XIC were due to species sharing similar $m / z$ but different charge states. 


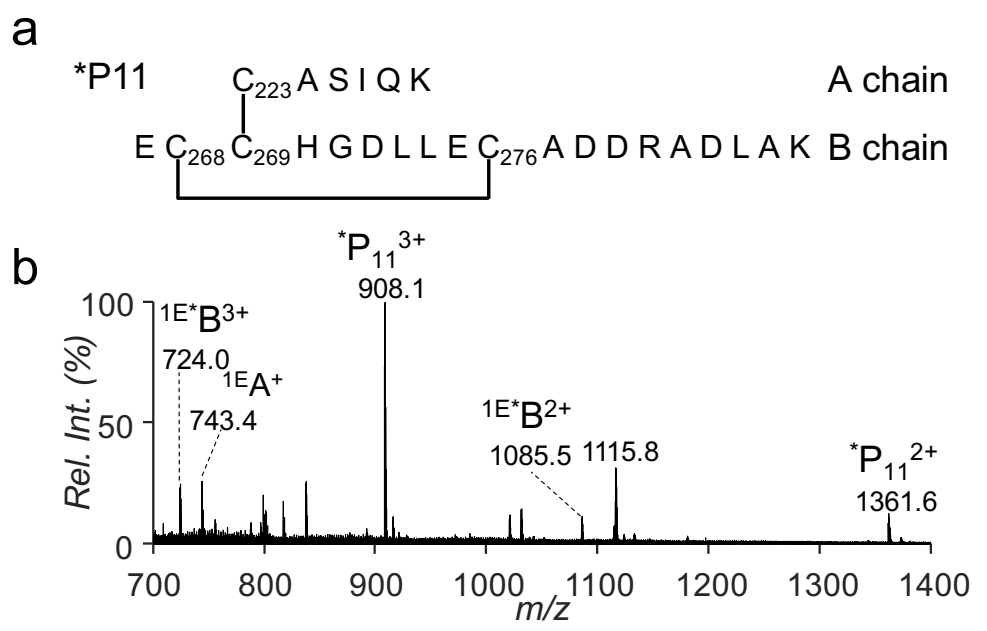

Figure S19. (a) Mis-cleaved *P11 peptide from trypsin digestion of BSA. (b) Positive ion mode MS $^{1}$ spectrum of the online disulfide-ene product of *P11 eluted at 24.4 min in Figure S18c. 
a

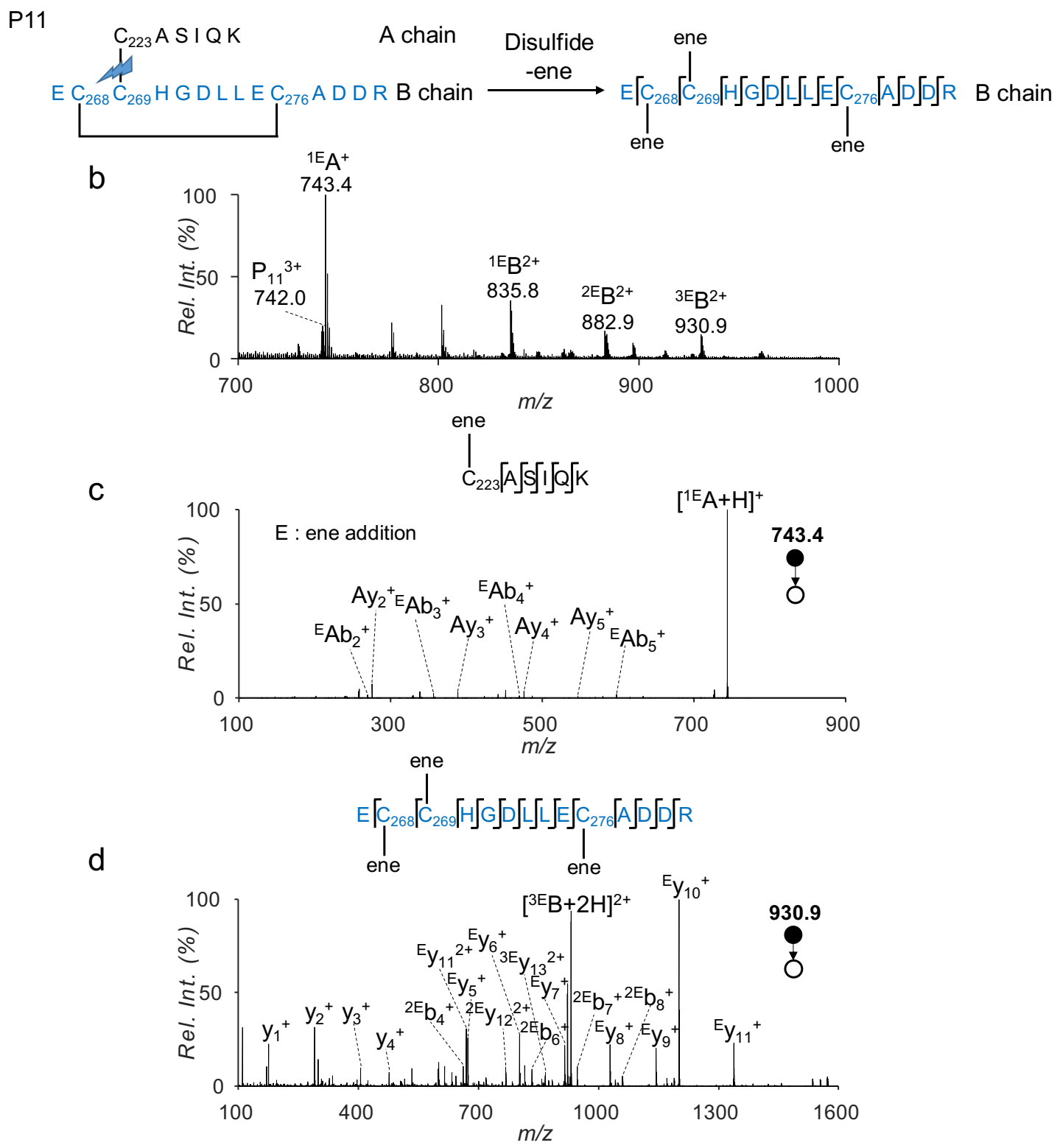

Figure S20. Analysis of P11 peptide from trypsin digestion of BSA. (a) Intact P11 and the fragmentation map of its disulfide-ene product. (a) $\mathrm{MS}^{1}$ spectrum of the disulfide-ene product of P11 peptide. $\mathrm{MS}^{2} \mathrm{CID}$ of disulfide-ene product of $\mathrm{P} 11$. (c) $\left[{ }^{\mathrm{E}} \mathrm{A}+\mathrm{H}\right]^{+}\left(\mathrm{m} / z\right.$ 743.4). (d) $\left[{ }^{3 \mathrm{E}} \mathrm{B}+2 \mathrm{H}\right]^{2+}$ $(m / z$ 930.9). 


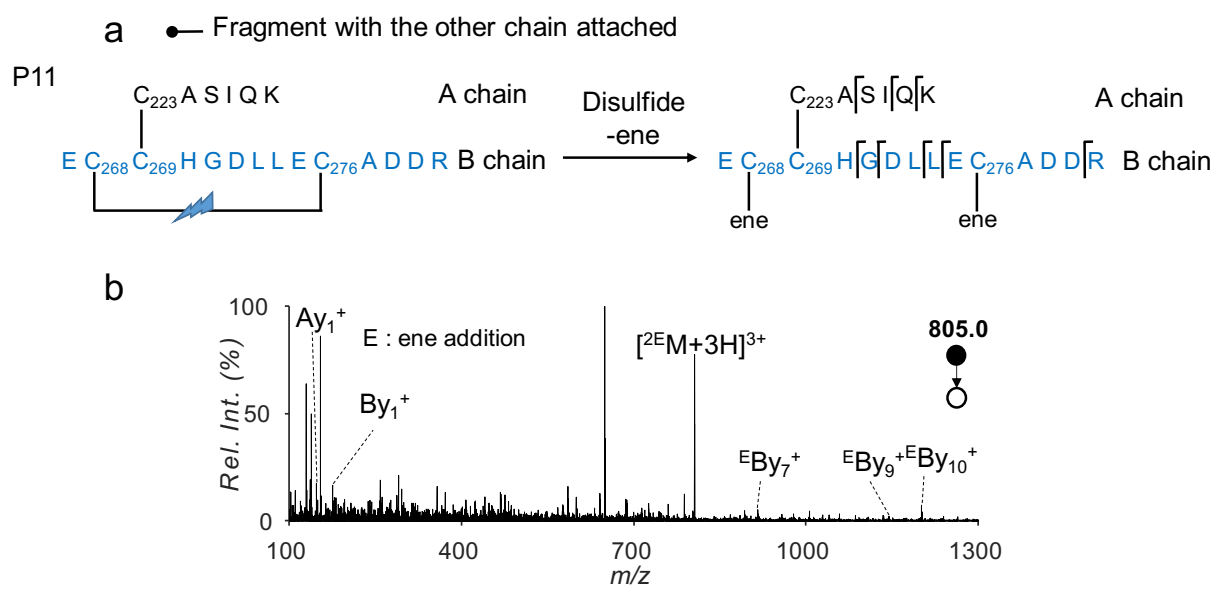

Figure S21. Analysis of P11 peptide from trypsin digestion of BSA. (a) Intact P11 and the fragmentation map of its disulfide-ene product. (b) MS ${ }^{2}$ CID of disulfide-ene product of P11 $\left(\left[{ }^{2 \mathrm{E}} \mathrm{M}+3 \mathrm{H}\right]^{3+}, m / z\right.$ 805.0).

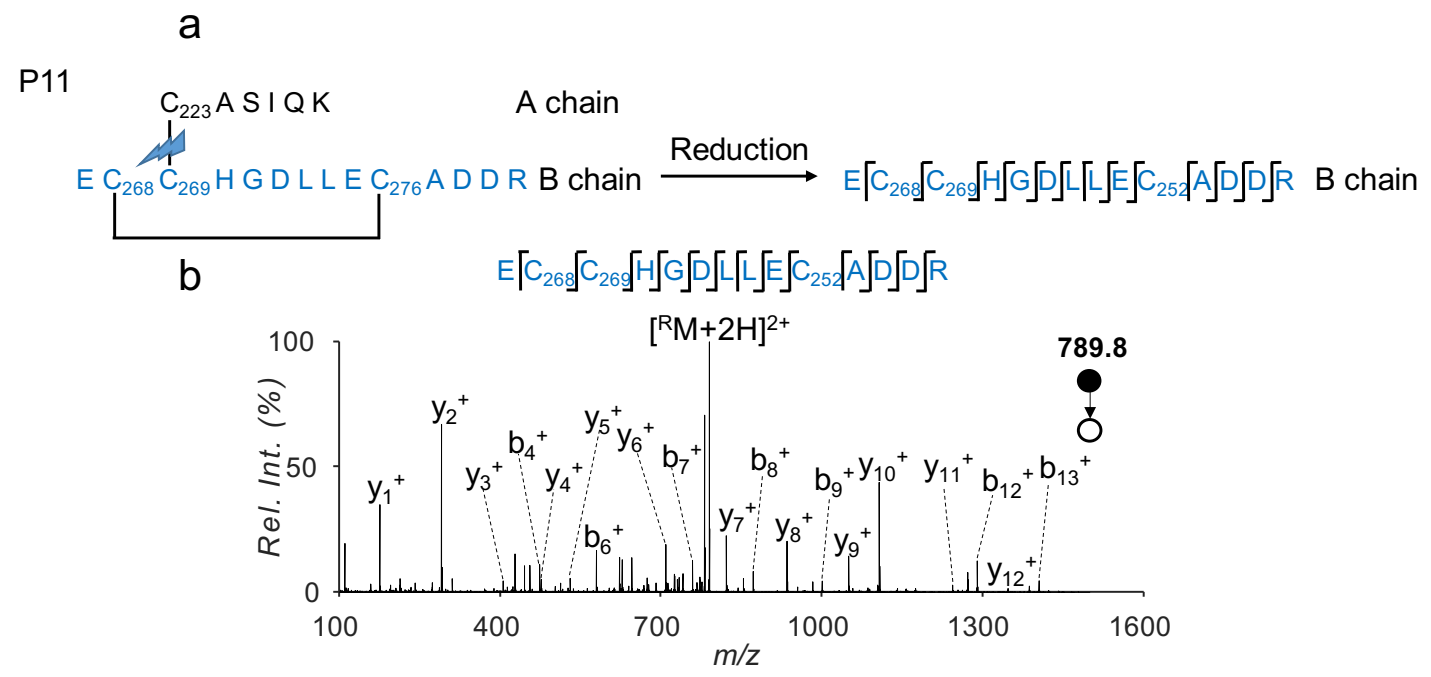

Figure S22. Analysis of P11 peptide from trypsin digestion of BSA. (a) Intact P11 and the fragmentation map of its reduced product. (b) $\mathrm{MS}^{2}$ CID of fully reduced product of P11 $\left(\left[{ }^{\mathrm{R}} \mathrm{M}+2 \mathrm{H}\right]^{2+}, m / z 789.8\right)$. 
a

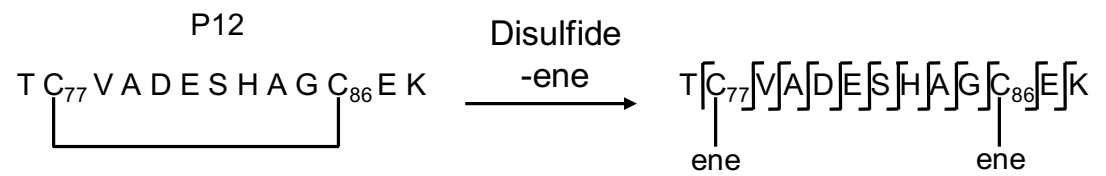

b

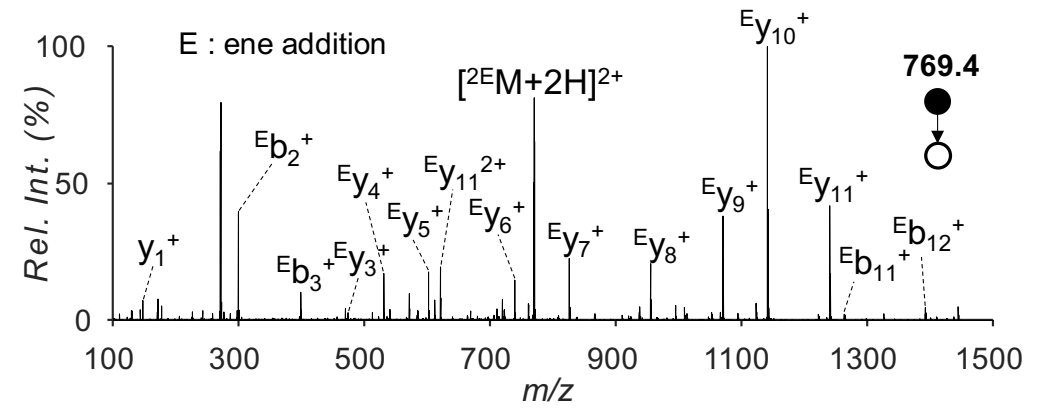

Figure S23. Analysis of P12 peptide from trypsin digestion of BSA. (a) Intact P12 and the fragmentation map of its disulfide-ene product. (b) $\mathrm{MS}^{2} \mathrm{CID}$ of disulfide-ene product of P12 $\left(\left[{ }^{2 \mathrm{E}} \mathrm{M}+2 \mathrm{H}\right]^{2+}, m / z 769.4\right)$. 
Table S2. Analysis of peptides containing disulfide bonds from tryptic digestion of BSA, their partial reduction-alkylation products, the theoretical and measured $\mathrm{m} / \mathrm{z}$ of the corresponding ions. P6 and P11 were not confirmed by MS ${ }^{1}$ due to an overlap $\mathrm{m} / \mathrm{z}$ with impurities; however, they were confirmed by $\mathrm{MS}^{2} \mathrm{CID}$. P9 and P10 were not detected.

\begin{tabular}{|c|c|c|c|c|c|c|c|c|}
\hline & peptide structure & $\begin{array}{l}\text { S-S fragment } \\
\text { MW/Da }\end{array}$ & $\begin{array}{l}\text { Retention } \\
\text { time/min }\end{array}$ & ene product & $\begin{array}{c}\text { Charge } \\
\left(\mathrm{H}^{+}\right)\end{array}$ & $\begin{array}{c}\text { partial reduction } \\
\mathrm{MW} / \mathrm{Da}\end{array}$ & $\begin{array}{l}\text { measured } \\
\mathrm{MW} / \mathrm{Da}\end{array}$ & error/ppm \\
\hline P4 & 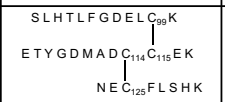 & $617.26(+6)$ & 30.2 & $\begin{array}{c}\text { SLHTLFGDELC C } C_{9 g} K \\
\text { ETYGDMADC } C_{114} C_{115} E K \\
\text { ene }\end{array}$ & $3+$ & 940.0726 & 940.0702 & -2.6 \\
\hline P5 & 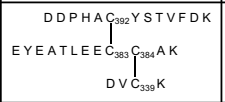 & $669.68(+5)$ & 24.3 & 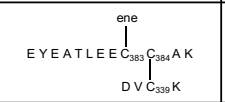 & $2+$ & 972.4269 & 972.42 & -7 \\
\hline P6 & 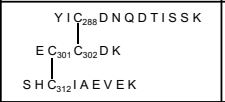 & $599.46(+5)$ & 23.6 & $\begin{array}{l}\sum_{E C_{301} C_{302} D K}^{\text {ene }} \\
I_{S H C_{321} 1 A E V E K}\end{array}$ & $2+$ & 852.3769 & - & - \\
\hline P7 & 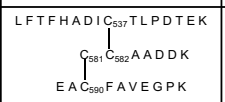 & $604.27(+6)$ & 31.9 & 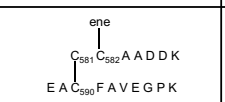 & $2+$ & 933.9086 & 933.901 & -8.1 \\
\hline P8 & 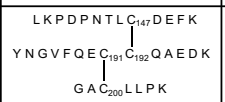 & $770.56(+5)$ & 31.0 & 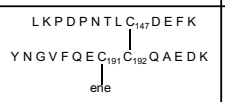 & $2+$ & 1082.1579 & 1082.1596 & 1.6 \\
\hline P9 & 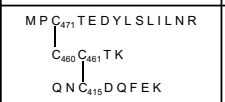 & $626.28(+5)$ & - & - & - & - & - & - \\
\hline P10 & 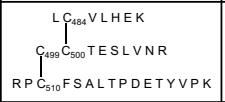 & $737.56(+5)$ & - & - & - & - & - & - \\
\hline P11 & 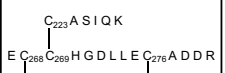 & $556.48(+4)$ & 22.1 & ene & $2+$ & 835.8355 & 835.8316 & -4.6 \\
\hline P11 & 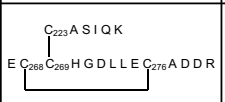 & $556.48(+4)$ & 22.1 & 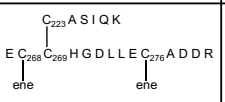 & $3+$ & 805.0258 & - & - \\
\hline P12 & TCTVADESHAG Ge K K & $674.27(+2)$ & 7.4 & $\begin{array}{l}\text { TC } \int_{7 T} V A D E S H A G C_{86} E K \\
\text { ene ene }\end{array}$ & $2+$ & 769.3494 & 769.3551 & 7.4 \\
\hline
\end{tabular}

